DOI: 10.1515/ausp-2016-0013

\title{
Barriers to Women Entrepreneurship: A Comparative Analysis between South Korea and Romania
}

\author{
Irina ROIBU \\ Hankuk University of Foreign Studies (Seoul, South Korea) \\ Department of Romanian Studies \\ roibuirina@gmail.com \\ Paula-Alexandra ROIBU \\ Alexandru Ioan Cuza University (Iaşi, Romania) \\ Doctoral School of Economic and Business Administration \\ roibu.paula@yahoo.com
}

\begin{abstract}
Even in the twenty-first century, women entrepreneurs from all over the world continue to encounter different types of barriers in their activity. Depending on their location, history, culture, etc. the restraints can be more or less strict, distinct or similar. This article analyses and compares the constraints that the women entrepreneurs from South Korea and Romania are encountering, barriers concerning the professional stereotypes such as smaller medium wages for women, difficulties in getting specific jobs, the traditional collective mentality and prejudices, the roles of women in society, the balance between professional and family/private life, as well as the maternity and child care systems. The analysis is based on the data provided by the Global Entrepreneurship Monitor, OECD and the World Bank, the legislations of the two countries and the literature related to the two social environments. The findings indicate that although there are many similarities between the two countries, such as smaller salaries for women, discrimination against women, difficulty to advance, conservative attitudes towards women, lack of ways to monitor and penalize discrimination, lack of successful women entrepreneurs, the number of women entrepreneurs in South Korea is significantly smaller than the number of Romanian ones. This is due to the South Korean stricter social environment, harsher work environment (with shorter holidays, longer working hours, obligatory group activities and stricter hierarchy), higher gender wage gap and poorer maternity and childcare legislation. ${ }^{1}$
\end{abstract}

Keywords: women, entrepreneur, barriers, Romania, South Korea. 


\section{Introduction}

Women's entrepreneurship has been recognized as an important source of economic growth in the last decades (OECD 2004). Women create jobs for themselves and for others, they come with different solutions to current problems than their male counterparts and they exploit the entrepreneurial opportunities in directions that men could not. However, they still represent a minority (OECD 2004). Women have lower participation rates in entrepreneurship than men and generally they tend to activate in different industries than men do (retail, education, service industries, etc.), sometimes perceived as being less important to economic development and growth (OECD 2004). Moreover, women are faced with specific obstacles (household work, family responsibilities, child rearing, etc.) and unless these are overcome, they cannot have access to the same opportunities as men. Other obstacles are related to the lack of role models in entrepreneurship, weak social status, gendering of entrepreneurship, access to finance, maternity and child care policies, etc. (OECD 2004). At the same time, depending on the area, society, culture, etc. the barriers that women entrepreneurs face can be more or less high.

Regarding the two countries chosen for this paper, Romania and South Korea, they experienced different histories, traditions, development, economic level, etc. and knowing the strict social environment that can be found in the majority of Asian countries related to women at work, we wanted to analyze which one of them has a more supportive environment and what the barriers that women entrepreneurs face are. The reasons for choosing these two countries start with the location of the two authors, one in South Korea and one in Romania, their interest in the topic and the worldwide increasing enthusiasm in topics related to this Asian country. The analysis has been made based on the literature related to the two countries' environments (social, political, etc.), the legislations of the two in this field and on the data provided by the Global Entrepreneurship Monitor, OECD and World Bank.

\section{Backgrounds}

The Universal Declaration of Human Rights, article 2, states the following: "Everyone is entitled to all the rights and freedoms set forth in this Declaration, without distinction of any kind, such as race, colour, sex, language, religion, political or other opinion, national or social origin, property, birth or other status" (United Nations 1948). This means that no woman should be deprived of the opportunity to be an entrepreneur. Throughout history, women struggled to gain personal and professional space, took risks, were divided between family and work, and "invented" jobs. Thanks to them, we can speak today of female entrepreneurship. Part of the results of their fight are considered to be March $8^{\text {th }}-$ International 
Women's Day; September $23^{\text {rd }}$ - International Day against Sexual Exploitation and Trafficking in Women and Children; November $25^{\text {th }}-$ International Day for the Elimination of Violence against Women. Despite all the victories and the fact that today women should have the same rights as men do, we cannot always speak of equality and partnership. The reasons why this happens are strictly related to the image of women in a society, and thus to the culture and the mentality of that society (Rosu 2015). Moreover, the entrepreneurship development, regardless of gender, is linked to economic trends, technological progress, demographic trends and social changes, every country being different. Regarding Romania and South Korea, before proceeding with the comparative analysis, it is imperative to first have a look at all the elements related to entrepreneurship, such as the professional stereotypes, the traditional collective mentality and prejudices, the roles of women in society, the balance between professional and family/private life, as well as the maternity and child care systems. The hypothesis that guided the analysis is that despite the different historical, economic and cultural background, the situation of female entrepreneurs in both countries is similar.

\subsection{Romania}

Romania is a former communist country, member of EU and NATO, that is still struggling to create an entrepreneurial culture in a strongly corrupted environment. The main concern here is gaining money and not the client, nor the quality of the product or the service. The years spent under communist control reduced the entrepreneurial capacities to zero, and people that now should be mature and represent a successful model to the young generations are missing. However, the year 2007 came with a new challenge for Romanians, after the country's entrance in the EU: they had to learn how to compete with their European counterparts. Many had the chance to activate in the European environment and to learn a great deal from that. Also, they started to have access to structural funds from the EU, which gave them the financial support to create new businesses and improve their activities (Piti 2010).

Based on data provided by the Global Entrepreneurship Monitor (GEM) and the European Commission (Scărlătescu 2013), in 2013 Romania was the first country from the EU in terms of entrepreneurship intentions, $27 \%$ of Romanians declaring they wanted to start a new business. However, in terms of sustainability of entrepreneurship initiatives, it was on the last but one place in Europe, more than half of the new companies not being able to survive the critical period of forty-two months (Scărlătescu 2013).

Regarding Romanian women, according to two Romanian proverbs, i.e. "Man should wear pants and the women skirts" ${ }^{2}$ and "A woman's place is in the

2 In Romanian: Omul să poarte nădragii şi femeia fustele. 
kitchen," ${ }^{3}$ the woman's place is inside the house, in the kitchen, the equality of chances remaining still a utopia. In order to understand a Romanian woman's role in the society, it is also very important to mention the religion and the place of a woman in it. Romania is composed of $86.45 \%$ of its citizens with Orthodox religion (INSSE 2013), which considers women inferior to men.

As Mihaela Miroiu, expert in feminism and gender studies in Romania said, although the communist era brought egalitarianism and women were supposed to work the same way as men did (in factories, agriculture, etc.), the lack of free expression and the control did not give women a big chance to become independent (qtd. in Ofiteru and Ion 2014). Nevertheless, due to the fact that the Romanians were $80 \%$ peasants before communism, men have never really financially supported the women, the latter having to earn their bread by themselves, meaning that Romania did not have many women as housewives. Romania is characterized by an education in the spirit of self-sacrifice, women coming on the second or third place in what concerns their importance, investment and food. Also, Romanian women are the ones who supported men during the crisis of the 1980s, in communism, and also in that of the 1990s, when due to deindustrialization men were left without jobs (Ofiteru and Ion 2014).

During communism, the system's biggest promise, equality, did not mean equality between sexes. However, the party and the state supported women to get involved in the public sphere, to break the economic barriers imposed by the old traditions and to leave the children in the public organizations' care. Ceauşescu named them "equal socialist workers" and "mothers of the nation" (Massino 2004).

There have been identified two distinct phases during the communist regime for highlighting the status of women: policies for empowerment at the beginning of communism (1948-1965) and aggressive pro-natalist policies (anti-abortion decree 1966-1989). During the debate "After twenty-five years. Communism in East Europe", Alina Hurubeanu explained that after the war, in Romania, there was an acute need of women labor and thus an intense propaganda of emancipation and freedom for women through work (qtd. in Pădurariu 2014). She also mentioned that women, through their efforts as producers, mothers and wives, contributed to the meeting and exceeding of the plan, to the blossoming of communism and of the country. Paid employment became the solution for women's emancipation and the way to demonstrate equality with men (Pădurariu 2014). The second period, also known as the "Golden Age," was characterized by a strict pro-natalist policy. The anti-abortion decree of 1966 represented a new stage in the standardization of the brutal status of women. They became more important for reproductive purposes, kept under strict control by every three months gynecology checks (especially for the women who worked in factories). 
Women were supposed to have at least four children by the age of forty-five, making Romania one of the strictest communist countries regarding abortion. There are two movies that present very clearly women's condition during that time: Children of the Decree (Decrețeii, Florin Iepan, 2005) and 4 months, 3 weeks and 2 days (4 luni, 3 săptămâni şi 2 zile, Cristian Mungiu, 2007), the latter being the winner of the Palme d'Or award at the 2007 Cannes Film Festival.

In 1973, Ceauşescu defined women's role and status during a meeting of the Communist Party's Central Committee: “The highest honor for women is to give birth, to give life and raise children. There can be nothing more dear for a woman than being a mother" (Banciu, Chipea and Bancila 2012). He was aware of the power, the talents and determination of women that were an important element in the construction of communist Romania.

After the fall of communism, the Constitution from 1991 acknowledged for the first time the equality between sexes: Title 1, Article 4 - "(2) Romania is the common and indivisible homeland of all its citizens, without distinction of race, nationality, ethnic origin, language, religion, sex, opinion, political affiliation, wealth or social origin." "Also after the fall of communism many laws concerning equality of chances appeared: 1999 - the law concerning paternity leave, 2000 - the law concerning the prevention and sanctions against discrimination, 2003 - the labor code, 2006 - National Strategy for equality between sexes 2006-2009, 2010 - National Strategy for equality between sexes 2010-2012, 2010 - the law concerning child care leave, monthly allowance for children, etc. Concerning maternity leave, the 2005 law which was updated several times until 2015 consists of: pregnancy leave - sixty-three days before birth; and confinement leave or maternity leave - sixty-three days after birth. The monthly child allowance represents $85 \%$ of the net average income earned in the last twelve months (European Commission 2016). There is also a parental leave that mothers can take: up to two years, with an allowance of $85 \%$ from the average net income earned in the last twelve months, maximum 1.200 lei/month (around $300 \$$ ). The children's allowances are as follows: 42 lei/month (around 10 \$) or 75 lei/month (around 14 \$) for the children that come from low-income families. ${ }^{5}$ Moreover, the employer is forbidden from firing a woman who is pregnant or is currently on maternity leave/parental leave and he/she has to receive her back on her previous position after the leave is finished. The situation is the same for men who take parental leave. Statistics show that $95 \%$ of the persons that take the parental leave resume their work at the end of it (Agerpres 2016). Regarding men

4 Translated from Romanian by the authors of the present study. Original text: "România este patria comună şi indivizibilă a tuturor cetățenilor săi, fără deosebire de rasă, de naționalitate, de origine etnică, de limbă, de religie, de sex, de opinie, de apartenență politică, de avere sau de origine socială."

5 http://legislatiamuncii.manager.ro/a/14521/mod-de-calcul-indemnizatie-crestere-copil-2014. html 
who take parental leave, the Romanian National Agency for Payments and Social Inspection declared that at the end of 2014, 137.000 people were on parental leave, out of which 15.153 were men (Alexa 2014). The Romanian National Press Agency released at the beginning of this year an analysis which indicates that only $4.5 \%$ of Romanian men who become fathers choose to take parental leave, compared to $42 \%$ for women (Agerpres 2016). However, by law, Romanian men have the right to five fully paid days of holiday in the first eight weeks from the birth of their child (Law 210/1999).

\subsection{South Korea}

On the other side is South Korea, with a society deeply influenced by Confucianism and patriarchy, where a woman's value was given by her position as obedient daughter, wife and mother, for the preservation of the bloodline. Moreover, men were seen as superior and leaders, while women were seen as inferior and blind followers (Ro 1998). Traditionally, women and men were separated inside the household, having separate spaces at their disposal (anbang for women and saranbang for men) (Lee 1996). Also, a woman, even after marriage, would not take the husband's name but she would be moved to her new family's record book (Ro 1998) and she would be obedient to them. She would not be allowed to remarry in case of divorce or death of the husband. In the 1940s, there still existed some cases of suicide after the husband's death.

In the late 1980s an interesting variation of traditional female roles was observed in the villages of Jeju Island, where women were economically self-sufficient due to the fact that they were working as divers in search of oysters, seaweed, etc. Their husbands took care of the household and children, in contrast with the Confucian norm (Savada and Shaw 1992). The women from this area are called "sea women," haenyeo in Korean. They were famous for being able to dive to depths of around sixty feet to find sea creatures to sell, while the husbands stayed at home and took care of the children and the house. Men were still in charge of the political affairs and other "manly" activities. Nowadays, however, due to the increasing tourism in the area, many male-dominated economic activities have been put in place and the need for their women to dive for food is not as big as before (Tudor 2012).

Modern South Korea is an androgenic country constructed by the traditional Korean neo-Confucian patriarchy, Japanese colonialism (1910-1945), the implementation of the US's political and social infrastructure, together with the Japanese military trained Korean former president Park Chung-Hee's dictatorship (1962-1979) that promoted masculine integrity and chastity upon women (Kim and Choi 1998). The military government fortified the idea of male domination and legitimized the subordination of women for the benefit of the country's 
development and declared "Korean mothers the sacred emblem of the Korean nation" (Kim and Choi 1998, 17).

In 1948, the Republic of Korea was established and women achieved constitutional rights for equality concerning education, work, public life, etc. but the war that followed (1950-1953) brought again many changes for women. Many became widows (16.1 percent in 1955) (Lee 2008) and the gender roles tradition had to be interrupted. Single mothers had to provide for their families and so their role experienced an upgrading. In the 1960s, during the economic development under state control, the Korean family system underwent many changes concerning the family planning project. If traditionally the Koreans prefer sons to daughters, the 1970s slogan changed that preference: "Son or daughter, let's just have two babies and raise them well" (Lee 2008). The 1980s came with another slogan: "Given the small territory, let's have just one child and live young” (Lee 2008). This slogan had a big influence on the current low birth rate in South Korea (1.210 in 2014, based on OECD's data), but put higher focus on the nuclear family (i.e. the parents and their child), leaving outside the couple's parents.

One of the factors that paved the road to South Korea's spectacular growth in the last decades was the quality of the labor force, women and men alike. In the 1960s, industrialization brought women jobs in manufacturing industries like foods, textiles, etc. Between the 1970s and 1980s the banking, the insurance, the service sectors demanded more and more women work force (Lee 2008). In 1988 the government passed the "Equal Employment Act” in support of women's protection against discrimination in work places (Lee 2008). The 1990s came with technology and more service industries and more women were invited to work. In 2006 the ratio of women participation in economic activities was 50.3 percent (Lee 2008).

The women who graduated in the 1980s or early 1990s did not have a high chance of using their education; they were strongly discriminated inside the companies and forced to quit after their marriage. Because of this, among the current leaders in their forties or fifties, female representation is low, only 4.7 percent of executives are women in the large Korean companies. The ones who graduated in the late 1990s and 2000s had different experiences, the male colleagues being more permissive and accepting, but still treating women as women "engineers" not as engineers, for example, and still surprised by the success of their female colleagues (Tudor 2012).

The South Korean corporate world is a male-oriented one and the wage discrimination is a difficulty that women still face, the wage gap being around $38 \%$ in 2013, based on OECD's Gender wage gap research findings (2013). The main reasons for this are related to education, experience and "the old boy's network," companies valuing who you know rather than individual qualifications (Lowe-Lee 2006). 
At work, the Korean women encounter, besides the small salaries, discrimination related to employment and promotion. In some cases there is also pressure from their colleagues or their friends/society to give up their jobs and career after marriage or having children (Kwon 2014). The ones who continue working face multiple tasking such as child rearing, wage earners, housekeeping duties, family and social obligations and expectations, due to the fact that women are still considered primarily responsible for raising children (Lowe-Lee 2006). The society, the literature, the social media still strongly sustain the image of women as mothers who sacrifice everything for their children and have a strong relationship with them (Kim 2013).

Compared to the old days, daughters/women in South Korea are seen as an asset and are supposed to get an education and find jobs, but companies still tend to choose men over women when hiring as the former are considered a better option on the long term, due to the high possibility that women might give up their job after marriage. This also happens because of the lack of childcare facilities, inflexible working environment, lack of paid maternity leave and security of being able to resume their activity after the leave is over (Kim, Lee and Shin 2014). The result of this is the M-curve pattern, which means that Korean women start working in large number after graduating, quit their jobs after having children and return to work after their children are grown, but on positions that are low-paid and have law added value (Tudor 2012).

South Korea is number three in the top ten countries in terms of the average annual hours worked, with 2057 hours per worker (OECD 2014). In Korea, China and Japan, the three countries of the Confucian belt, there is a belief in total dedication and any job has to be done excessively. The culture of working hard and long hours has post-Korean-War origins, when the country was in ruins and the leaders from 1950-1990 promoted the long working hours of employees as the path to success, the ones who did it being glorified. In 2009 Samsung Electronics adopted flexible work hours, but old habits die hard because employees are trying to impress the management and do not want to lose their jobs. Another important aspect of the Korean culture is the "Business drinking" or Kyojesul in Korean, an integral part of maintaining interpersonal relationships with the companies' customers, suppliers, but also inside the company, between coworkers, for building the company's loyalty and spirit. Generally, these “drinking outings” take a long time, until late in the night, and heavy drinking is a must, no excuse is accepted (Lafayette de Mente 2014). This is hard for married women and mothers because of the housework that also needs to be done after work and the time and attention that the family needs. Thus it is easy to understand why companies prefer men instead of women, the latter not being as resistant to drinking as men are, who had been trained with respect to the drinking etiquette in a highly hierarchical society during their military service (two years of obligatory service) (Novak 2015). 
In 1987 a maternity protection law was introduced, which granted pregnant women ninety days of paid leave and their right to return to work. Yet, in practice, things move slower and companies still tend to violate the law. The government is also encouraging men to take a "father's month" off work, but Korean men do not even want to take the holiday they are entitled to, due to the worry that their absence from work will damage their career and relationship with the other colleagues. According to a survey released by the Ministry of Employment and Labor in 2015, the number of men that took paternity leave in the first half of 2015 was 2.212, up 40.6 percent compared to the same period a year before. However, these numbers only account for 5 percent of those taking time off for childcare, indicating a bigger burden for women than for men in raising children in South Korea. In 2001, the first maternity leave legislation was introduced and some improvements have been made, with more than three hundred laws having been changed since 2005 in order to increase gender equality (Tudor 2012).

Moreover, in 2001, the Presidential Commission on Women's Affairs that was established in 1998 became the Ministry of Gender Equality, after being elevated and expanded. This new ministry covers six basic areas:

to revise and establish laws and rules that involve discrimination in any sector and to increase the representation of women, to facilitate women's employment and provide support for female workers, to increase educational opportunities for women to be competitive in the labor market, to provide social welfare policies for women, to promote women's involvement in various social activities including volunteer work and women's organization activities, and to strengthen the cooperation of Korean women's organizations with international women's organizations. (Korean Overseas Information Service 2016)

Among the present South Korean president's policies childcare and female employment are of utmost interest. A good childcare support and more flexible hours could increase the economic participation among women and could fix the $\mathrm{M}$ curve in the future: high labor force participation rate in the twenties, low in the thirties until their forties (becoming one of the lowest globally, according to a report by the World Economic Forum in 2013) and again high after their children are grown up. However, the problem seems to be the traditional culture. For example, South Korean men are not supposed to do housework. A study conducted by OECD revealed that among developed countries, South Korean men spend only a total of forty-five minutes daily doing housework, which ranks the country as lowest in sharing of house duties (2014). 


\section{Comparative Analysis between South Korea and Romania}

As seen in the previous chapter, the two countries chosen for this study, South Korea and Romania, are different in their location, history, culture, traditions, economy level, religion, etc. On one side, South Korea experienced an impressive economic growth during the second half of the twentieth century. If in the 1960s it was a poor country with limited social freedoms, today it is one of the most advanced societies, economically and technologically as well. On the other side, Romania is still in transition after many decades under communist control and it is fighting with corruption, but it experienced one of the highest economic growths among the EU countries in 2015 (Agerpres 2015), it is rich in land and resources and it is a strong manufacturing base with a low-cost work force.

In order to make a clearer distinction between the places of women in the two countries and to understand the differences, the next table provides statistical information:

Table 1. Statistical information: South Korea and Romania.

\begin{tabular}{lcc}
\hline Country name & South Korea & Romania \\
\hline Population in 2014 & 50.02 million & 19.91 million \\
\hline Female population & $50.3 \%(2014)$ & $48.7 \%(2013)$ \\
\hline Female labor force & $41.61 \%(2013)$ & $44.62 \%(2013)$ \\
\hline Total fertility rate & $\begin{array}{c}1.25 \text { children/woman } \\
(2014)\end{array}$ & $\begin{array}{c}1.32 \text { children/woman } \\
(2014)\end{array}$ \\
\hline $\begin{array}{l}\text { Female representation on } \\
\text { boards }\end{array}$ & $1 \%(2012)$ & $11.9 \%(2013)$ \\
\hline Female CEOs & $0.73 \%(2013)$ & $10.0 \%(2013)$ \\
\hline Women in Parliament & $15.7 \%$ & $11.7 \%$ \\
\hline Women presidents & 1 & 0 \\
\hline
\end{tabular}

Source: World Bank - www.worldbank.com, Trading Economics - www.tradingeconomics.com and Index Mundi - www.indexmundi.com

Regarding the weak political representation in both countries, the main reasons for this are prejudice and discrimination, the process of socialization and communication of women, family responsibilities, etc. (Vass 2015). In South Korea's case, it is also important to take into consideration the strict Confucian society that marginalized women from the political sector, women being considered passive, obedient, soft, while men aggressive, active, and dominant. However, the inauguration of the first woman president of South Korea in 2013 was a turning point in the place of women in this country's politics (Resos 2014).

In Romania's case, if in communism women were seen as equal in work places, 
as supporters for the building of the nation, in reality they did not have any power. After the fall of communism, women stayed away from power mainly due to the image that Elena Ceauşescu (wife of Nicolae Ceauşescu) left about women in power (participation not based on competence). However, during the transition period women started to get more involved but the reasons mentioned before plus the high number of corruption scandals in politics keeps them far from it. Also, the Romanian media rarely offers enough time to women in politics, which makes them invisible in the public eye. And when the press gets interested in a woman politician, it is more for her appearance than for her capabilities or position. For example, a search on Google for the topic "women in Romanian politics" will show more articles about the most beautiful politicians, not about the most qualified ones (Glavan 2014).

As seen in the table above, although South Korea has a higher percentage of female population, in terms of labor participation Romania ranks higher. The difference is not big, and actually if we consider the percentage out of the total population, the real number of women working in South Korea is at least double the number of Romanian female workers. Concerning the number of women on boards and CEOs, Romania accepts ten times more women in leading positions, an aspect possible also due to a more relaxed work environment, shorter extra working hours, no need to socialize after work, higher support in maternity leave and security of still having the job after returning.

Based on OECD's data, in South Korea 27.7 percent of the entire female work force have part-time jobs (Ryan 2014). Also, female college graduates do not have an employment rate higher than women with only compulsory education. One reason for these might be the gender pay gap, South Korean women being paid only around 44 percent of a male salary (Ryan 2014). In order to change this situation and also to enjoy more stable fertility rates, the Ministry of Gender Equality and Family's budget promised to increase the childcare support (Ryan 2014).

Regarding the percentage of university graduates by sexes, in Romania, in 2013, there were $57.8 \%$ women and $42.2 \%$ men (INSEE 2014). According to OECD data, in 2011 around $48 \%$ of the South Korean women were university graduates, while college completion rate was on average 10\% higher than men's (Chamie 2014). Despite the educational gains, women continue to fall behind men in income, politics, employment, business ownership, etc. This is due to societal expectations and cultural norms but also to the fields they choose to study: men dominate majors such as engineering, computer science, manufacturing, while women focus on education, humanities and arts, health and welfare, fields that are less remunerative (Ryan 2014).

Many women that graduate with high dreams of a good future, when faced with the inequalities and the lack of job opportunities, decide to emigrate. While South Koreans emigrate due to long hours of work, jobs that are unstable or 
unfit for their level of education, and the high unemployment rate, Romanians emigrate because they consider their country to be poor, corrupted and without opportunities (Stănculescu and Stoiciu 2012).

Korean women who despite the above mentioned facts join the labor force in their country and advance their careers interrupt their employment for motherhood responsibilities, which causes a fall behind men on their work capabilities. Also, women are more likely to take time off from their job to take care of family matters, including care for elderly relatives (Chamie 2014).

Related to the ease of doing business, in 2015 the World Bank Group ranked South Korea as number four and Romania as number thirty-seven out of one hundred and eighty-nine economies (2016a and 2016b). The analysis also shows that the time for starting a business is much shorter in South Korea (four days, three procedures being necessary) (World Bank Group 2016a) compared to Romania (eight days, with five procedures) (World Bank Group 2016b).

Concerning the Female Entrepreneurship Index 2015, Romania is located on the thirty-third position with a score of 49.4 and South Korea on the fortythird position with a score of 40.1. The same research also indicated that South Korea, together with Japan, Taiwan and Singapore create the right conditions for entrepreneurship among women (Terjesen and Lloyd 2015).

\section{FEI Results by Country}

\begin{tabular}{|c|c|cl|cl|c|c|}
\hline Pillar & Indicator & Pillar & Indicator & Pillar & Indicator & Pillar & Indicator \\
\hline 1 & Opportunity Recognition & 4 & Know an Entrepreneur & 8 & Highly Educated Owners & 12 & New Technology \\
1 & Equal Rights & 4 & Internet and Networks & 8 & SME support and training & 12 & R\&D Expenditure \\
1 & Market Size & 5 & Executive Status & 9 & Innovativeness & 13 & Business Gazelles \\
2 & Perc. Of Skills & 5 & Access to Childcare & 9 & Monopolized Markets & 13 & Female Leadership \\
2 & Secondary Education & 6 & Opportunity Business & 10 & Entrepreneurship Ratio & 14 & Export Focus \\
3 & Willingness to Start & 6 & Bus Freedom \& Movement & 10 & Labor Force Parity & 14 & Globalization \\
3 & Business Risk & 7 & Tech Sector Business & 11 & New Product & 15 & 1 st tier financing \\
& & 7 & Tech Absorption & 11 & Technology Transfer & 15 & 3 rd tier financing \\
\hline
\end{tabular}

Individual level indicators are listed in black; Institutional level indicators are listed in blue

Highest score

Lowest score

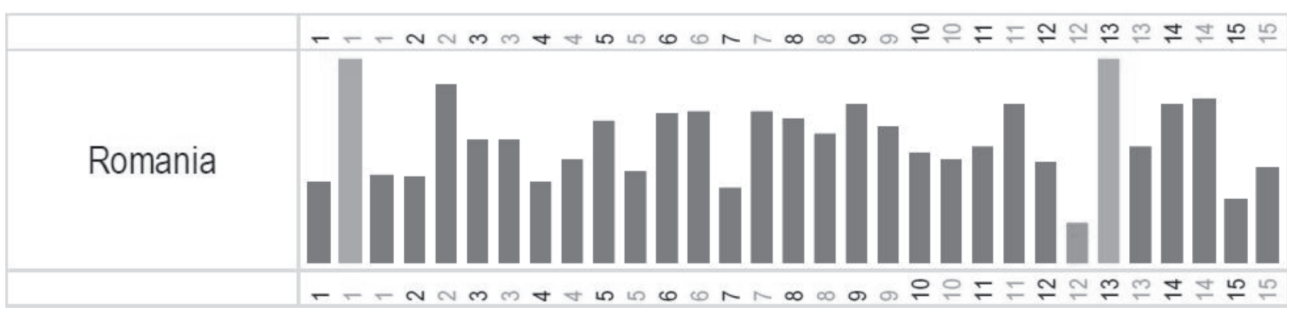




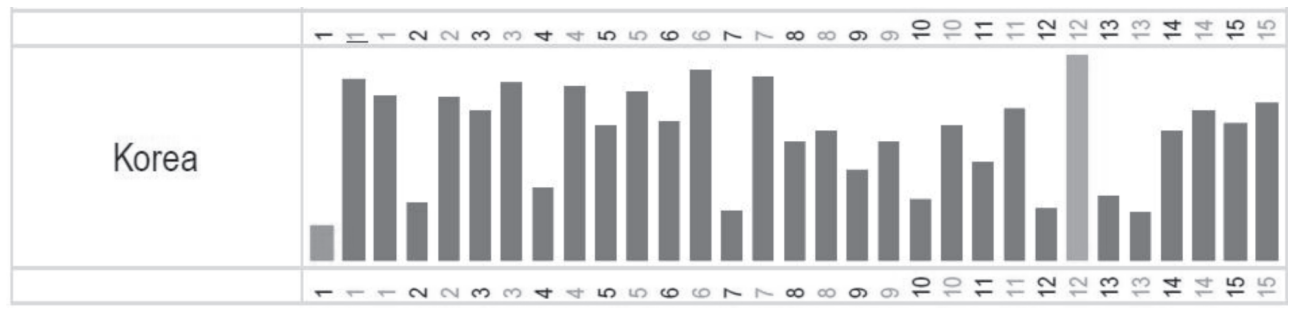

Source: Terjesen, S.; Loyd, A., 2015 Female Entrepreneurship Index. Global Entrepreneurship and Development Institute, p. 25, 33

Table 2. FEI Results by country.

As indicated in the FEI analysis's results by country, Romania ranked the highest in the Equal Rights area and Business Gazelles, Number 2 in Secondary Education and the lowest in New Technology, while South Korea got the highest score in New Technology, middle high in Tech Absorption, Bus Freedom and movement and lowest in Opportunity Recognition.

In Romania women entrepreneurship is supported by measures and actions taken specifically for women or indirectly by encouraging entrepreneurship in general. Such measures are financed from the national budget or from European funds and are supported by public or private institutions. The European projects that encourage entrepreneurship are in high number, so just a few will be mentioned here: Erasmus for Young Entrepreneurs, "Youth in action," European Social Fund, etc. The Romanian entrepreneurial environment promotes women entrepreneurs through the improvement of the access to financing and to different supportive networks and through projects as "Women Entrepreneurs in Rural Areas,"6 "Feminine Entrepreneurship,"” “A Better Future for Women,"8 etc. (Rosu 2015). Based on the findings of Romania's National Statistics Institute, in 2005 around $38 \%$ out of the total of Romanian enterprises were led by women, and in 2015 the female unemployment rate was $5.9 \%$, lower than that of men, which was of $7.2 \%$ (INSSE 2016).

In South Korea's case, in order to improve women entrepreneurs' economic activities, the Government has established the "supporting law for women enterprises" and many local government services together with the Ministry of Gender Equality and Family have created and operate several support programs. They give assistance for locating funds, international expanding, management innovation trainings, development of brands, etc. (Lee, Sohn and Yong 2011).

In what concerns the percentage of enterprises owned by women in South Korea, it is increasing continuously: in 2011 it was $36 \%$, out of which $93 \%$ were

6 In Romanian: "FAR - Femeia antreprenor in Rural"

7 In Romanian: "Antreprenoriatul la feminin"

8 In Romanian: "Un viitor mai bun pentru femei" 
small-scale enterprises with maximum five employees and were related to the service industry and retail. In 2004, Korean women entrepreneurs exported approximately 2.13 billion dollars, less than $1 \%$ of Korea's exports (Lee, Sohn and Yong 2011).

The 2013 GEM Global Report divided the economies in three categories: factordriven economies, efficiency-driven economies and innovation-driven economies. As probably expected, Romania and South Korea belong to different categories, Romania to the second and South Korea to the third (2013a, 10). This indicates that while South Korea is a generator of new knowledge, Romania is dominated by imitation (GEM 2014, 9). Based on the key indicators of GEM, TEA (total earlystage entrepreneurial activity) rate was $6.9 \%$ in 2013 in South Korea (GEM 2013a, 3 ) and $11.3 \%$ in 2014 in Romania (GEM 2013a, 16). In entrepreneurial intention Korea only rated 13\% (GEM 2013a, 14) while Romania rated 32\% (GEM 2013a, 16). In terms of fear of failure both countries rated similar numbers, Romania $47 \%$ (GEM 2013a, 32) and South Korea 44\% (GEM 2013a, 13). Female TEA in 2013 was $3.9 \%$, compared to $9.7 \%$ for men in South Korea ( GEM 2013a, 16).

Other numbers and percentages are as follows:

Table 3. Key indicators - South Korea and Romania.

\begin{tabular}{|c|c|c|c|}
\hline & Romania & $\begin{array}{l}\text { South } \\
\text { Korea }\end{array}$ & Comments \\
\hline $\begin{array}{l}\text { Financial environment related with } \\
\text { entrepreneurship }\end{array}$ & 2.43 & 2.85 & \\
\hline Government policies bureaucracy, taxes & 2.24 & 3.01 & \\
\hline Government programs & 2.51 & 2.98 & \\
\hline Education and training & 2.68 & 2.26 & \\
\hline R\&D transfer & 2.59 & 2.42 & \\
\hline $\begin{array}{l}\text { Professional and commercial } \\
\text { infrastructure }\end{array}$ & 3.09 & 2.41 & \\
\hline Market dynamics & 3.14 & 2.96 & \\
\hline $\begin{array}{l}\text { Physical infrastructure and service } \\
\text { access }\end{array}$ & 2.89 & 4.16 & \\
\hline $\begin{array}{l}\text { Cultural, social norms and society } \\
\text { support }\end{array}$ & 2.61 & 3.08 & \\
\hline Support for female entrepreneurship & $\begin{array}{l}\text { Numbers } \\
\text { missing }\end{array}$ & 2.87 & \\
\hline Interest for innovation & & 3.34 & $\begin{array}{l}\text { Only for } \\
\text { innovation } \\
\text { driven cou }\end{array}$ \\
\hline
\end{tabular}


In the case of South Korea, GEM declared that despite a slight growth in 2013's entrepreneurial activity, the country still had low levels of entrepreneurial education, youth and female entrepreneurship. Moreover, the research indicates that South Korea's results are low, compared to other innovative-driven economies like the USA, Finland and Singapore ( 2013b, 1).

Among the factors that positively affect the entrepreneurial environment in South Korea there are the good physical infrastructure, market dynamics and effective government policies (the development of a "Creative Economy" with focus on improving entrepreneurial education at all levels and assisting entrepreneurs in fields like secure financing, service infrastructure, etc.). Among the challenges for the future, GEM highlights the necessity of changes in the entrepreneurship policies and in the culture of entrepreneurship by modifications in the education system, support for professional infrastructure, etc. Related to women entrepreneurship, the present weak levels should be tackled by identifying role models, by improving the societal view of female entrepreneurs and by providing specific governmental programs and family support, such as day-care centers (GEM 2013b, 1).

In Romania's case, the factors that affect positively the entrepreneurial environment are the market dynamics, the legal and physical infrastructure. Also, due to an increase in the number of established business owners in the last years, the proportion of people involved in any kind of entrepreneurial activity has increased, becoming one of the highest in the Central and Eastern Europe region. The biggest constraints are regulations and taxes, the availability of financial resources, and entrepreneurial education. With respect to the challenges for the future, Romania should improve the access to finance, the promotion of entrepreneurial education and should create better government policies that can provide real support to entrepreneurs (GEM 2014, 1).

In South Korea the ratio of male participation in entrepreneurship is $10.8 \%$, four times more than women's, which is $2.3 \%$. Compared to the other innovativeoriented countries where the rate is only double in favor of men, South Korea's is extremely high (GEM 2013b, 16). To resolve this issue, the GEM report proposes improvements of the social perceptions through government programs, efforts in discovering and fostering competent female entrepreneurs, supportive structures for working mothers, such as day care centers and more education programs for female entrepreneurs (GEM 2013b, 1).

In Romania's case, the GEM analysis also indicates the fact that Romanian women consider themselves having the required knowledge and skills to start a business (76.71\% compared to men $84.33 \%$ ), but the share of those who think that the fear of failure will stop them from starting a business is almost the double of that of men (46.22\% for women and $29.62 \%$ for men) (GEM 2014, 33-34). The Romanian physical infrastructure (roads, utilities, communication, waste 
disposal) that supports the new and growing firms is in need of improvement, Romania ranking the lowest among the EU's efficient-driven countries: Croatia, Hungary, Lithuania and Poland (GEM 2014, 43).

In the end, it is important to mention the immediate necessity of more female labor participants, especially in South Korea, where the aging society and the future pension fund issue are pressing. By 2026, 23 percent of the population will be aged over sixty-five, due to the low birth rate (1.2 children on average), high costs for children rearing (around 230.000US\$ ${ }^{9}$ ) and insufficient childcare policies (Tudor 2012).

\section{Conclusions}

The concept of equality between sexes exists both in Romania and South Korea in theory and legislation, but in reality societies consider women as the only ones responsible for the household and men as responsible for providing the income, with the difference that in South Korea women are the "heads" of the family in that they receive their husbands' salary and manage it. In the last decades, women's necessity of getting out of the household and working grew significantly due to increasing economic issues, causing a double burden for working wives and mothers.

At work, women from both countries have to deal with smaller salaries, discrimination, difficulty to advance, etc. This is mainly due to the patriarchal societies and conservative attitudes towards women, the lack of legal mechanisms and institutions to monitor and penalize discrimination. Other reasons, as found in the research, are related to the family's constitution and the role of each member in it, to school, mass media, civil society and political sphere.

A difference is found in the existence and implementation of maternity leave for working mothers. Romania ranks higher with a more supportive legislation for parental leave (for mothers or fathers), better childcare institutions and parents' integration after their return in the office. Also, Korea's work environment comes with more requests related to working hours, shorter holidays, obligatory group activities (especially dinners and drinking) and stricter hierarchy that make it harder for women to succeed on long-term due to their home responsibilities.

Other barriers that were found in both countries are related to the lack of successful female entrepreneur examples that could motivate other women to get more involved, the lack of confidence that generates fear in innovation and taking decisions, presenting new ideas, etc. Further barriers are common with men's: financial difficulties (for example, South Koreans complain that the access to funding is easier for bigger companies than smaller ones); difficulties in

$9 \quad$ Numbers according to Korea Institute of Health and Social Affairs. 
finding proper contracts for business, lack of information, pressure of taxation, bureaucracy (higher in Romania than in South Korea) and lack of modern technology (again higher in Romania, compared to South Korea). It is important, however, to remember that the two countries are part of different levels of entrepreneurship countries: innovation-driven for South Korea and opportunitydriven for Romania, which puts them in different stages of economic development. Moreover, by choosing a woman president in 2013, Korea seems to have opened the gate towards gender equality and support for women entrepreneurship and other female-related issues.

However, Romanian and Korean women entrepreneurs seem to have the same fate and to be hindered in their successful careers by the same barriers, despite the different backgrounds. The need to involve more women and in better conditions in the labor sector is pressing especially the government of South Korea, due to the aging society and future pension fund issues, but Romania does not fall behind either since the economic growth and the path towards an innovationdriven country requires the help of all citizens.

Nevertheless, whatever the future will bring, women will always have power. Both in Romania as well as in South Korea history has shown many times that women were able to pass over difficulties, political changes and economic struggles with strength, a strong sense of responsibility, and sometimes with more diplomacy than men were.

\section{Works Cited}

Banciu, Viorica, Floare Chipea and Ionut Bancila. 2012. "The Social Status and Image of the Romanian Woman Presented in the Nationalist Discourses of the Dictator Nicolae Ceauşescu." IPEDR vol. 34: 112-116. http://www.ipedr.com/ vol34/022-ICHHS2012-H10036.pdf. (Last accessed 10 February 2016)

Kim, H. Elaine and Chungmoo Choi, eds. 1998. Dangerous Women. Gender and Korean Nationalism. New York and London: Routledge.

Kim, Jinyeong, Jong-Wha Lee and Kwanho Shin. 2014. Gender Inequality and Economic Growth in Korea. Seoul: Korea University Press. http://econ.korea.ac.kr/ jwlee/papers/Gender\%20and\%20Korea\%20KLS. $p d f$. (Last accessed 12 January 2016)

Lafayette de Mente, Boye. 2014. The Korean Way in Business. Singapore: Tuttle Publishing.

Lee, Bae-young. 2008. Women in Korean History. Seoul: Ewha Womans University Press.

Lee, Helie. 1996. Still Life with Rice. New York: Touchstone Rockefeller Center. 
Lee, Jong Ha, So Young Sohn and Han Ju Yong. 2011. "How Effective Is Government Support for Korean Women Entrepreneurs in Small and Medium Enterprises?" Journal of Small Business Management 49(4): 599-616. https://www.researchgate.net/publication/228270175_How_Effective_Is_ Government_Support_for_Korean_Women_Entrepreneurs_in_Small_and_ Medium_Enterprises (Last accessed 15 March 2016)

Lowe-Lee, Florence. 2006. Korean Women: You Have Come a Long Way. Korea Economic Institute of America. http://www.keia.org/publication/koreanwomen-you-have-come-long-way (Last accessed 12 January 2016)

Resos, Archie. 2014. "The Empowerment of Women in South Korea." Journal of International Affairs, Online edition. Columbia University. http://jia.sipa. columbia.edu/online-articles/empowerment-women-south-korea/.

(Last accessed 10 February 2016)

Ro, Hea-Sook, ed. 1998. Korean Women and Culture, Studies on Women, Series II. Seoul: Research Institute of Asian Women, Sookmyung Women's University. Rosu, Camelia Augusta. 2015. "Antreprenoriatul feminin si barierele de gen." ["Female Entrepreneurship and Gender Barriers."] http://paemfortis.ro/ antreprenoriatul-feminin-si-barierele-de-gen/(Last accessed 20 February 2016) Savada, Andrea Matles and William Shaw. 1992. South Korea: A Country Study. Washington: Federal Research Division, Library of Congress.

Stănculescu, Manuela and Victoria Stoiciu. 2012. The Impact of the Economic Crisis on the Labor Migration from Romania. http://www.fes.ro/media/ publications/Carte_migratiei_EN_final.pdf(Last accessed 22 March 2016) Tudor, Daniel. 2012. Korea: The Impossible Country. China: Tuttle Publishing. Vass, Andreea. 2015. Consultare publică cu privire la îmbunătățirea reprezentării politice de gen în Romania. [Public Consultation on Improving Gender Representation Policy in Romania.] Forum: Equal Participation in Decision Making. http://www.femeileinpolitica.ro/. (Last accessed 17 March 2016)

\section{Websites}

Agerpres. 2015. "Romania lider în UE la creşterea economică în trimestrul al treilea." ["Romania Leader in the EU in Economic Growth in the Third Trimester.] http://www.agerpres.ro/economie/2015/11/13/romania-lider-inue-la-cresterea-economica-in-trimestrul-al-treilea-12-35-04 (Last accessed 20 March 2016)

Agerpres. 2016. "Doar 4.5\% dintre barbatii romani opteaza pentru un concediu de crestere a copilului." ["Only 4.5\% of Men Opt for Child Rearing Leave.”]. http://www.agerpres.ro/social/2016/02/15/doar-4-5-dintre-barbatii-romaniopteaza-pentru-un-concediu-de-crestere-a-copilului-analiza--10-57-57 (Last accessed 22 March 2016) 
Alexa, Aurelia. 2014. ANPIS: peste 15.000 de barbati sunt in concediu de crestere a copilului. [ANPIS: Over 15.000 Men Are on Parental Leave.] http:// www.mediafax.ro/social/anpis-peste-15-000-de-barbati-sunt-in-concediu-decrestere-a-copilului-13730527 (Last accessed 23 March 2016)

Chamie, Joseph. 2014. Women More Educated Than Men but Still Paid Less. Yale Global. http://yaleglobal.yale.edu/content/women-more-educated-menstill-paid-less-men (Last accessed 19 March 2016)

Constitutia Romaniei. 1991. [The Constitution of Romania.] http://www.cdep. ro/pls/dic/act_show?ida=1\&idl=1\&tit=1\#t1c0s0a4 (Last accessed 5 February 2016)

European Commission. 2016. "Romania - Maternity." http://ec.europa.eu/ social/main.jsp?catId=1126\&langId=en\&intPageId=3261 (Last accessed 15 March 2016)

GEM. 2013a. Global Report. http://www.gemconsortium.org/report (Last accessed 15 March 2016)

GEM. 2013b. South Korea Report. http://www.gemconsortium.org/countryprofile/125 (Last accessed 15 March 2016)

GEM 2014. Romania Report. http://www.gemconsortium.org/country-profile/103 (Last accessed 15 March 2016)

Glavan, Madalina. 2014. Femeile si politica in Romania. [Women and Politics in Romania.] http://www.contributors.ro/analize/femeile-si-politica-in-romania/ (Last accessed 17 March 2016)

INSSE Institutul National de Statistica Romania [National Institute of Statistics Romania]. 2013. "Ce ne spune recensamnatul din 2011 despre religie?" ["What Does the 2011 Population Census Tell Us about Religion?"] http://www.insse.ro/cms/files/publicatii/pliante\%20statistice/08Recensamintele\%20despre\%20religie_n.pdf (Last accessed 5 February 2016)

INSSE. 2014. "Sistemul educational 2014." ["Educational system 2014."] http://www.insse.ro/cms/files/statistici/comunicate/com_anuale/sistem\%20 educational/sistemul\%20_educational_2014_r.pdf(Last accessed 17 March 2016)

INSSE. 2016. "Ocuparea si somajul.” [“Employment and Unemployment."] http://www.insse.ro/cms/sites/default/files/com_presa/com_pdf/somaj_ tr4r_15.pdf (Last accessed 10 February 2016)

Kwon, Michelle. 2014. "South Korea's Woeful Workplace Inequality." The Diplomat. http://thediplomat.com/2014/05/south-koreas-woeful-workplaceinequality/. (Last accessed 12 January 2016)

Kim, Joseph. 2014. In-depth: South Korea's Fix-all 'Childcare'. https:// asiancorrespondent.com/2014/04/in-depth-south-koreas-fix-all-childcare/ (Last accessed 12 January 2016) 
Kim, Seong-kon. 2013. "Korean Mother: A Cultural Icon.” Korea Herald. http:// www.koreaherald.com/view.php?ud=20130917000515 (Last accessed 20 December 2015)

Korean Overseas Information Service. 2016. "Women’s Role in Contemporary Korea." http://asiasociety.org/education/womens-role-contemporary-korea (Last accessed 17 March 2016)

Law 210/31 December 1999 http://www.cdep.ro/pls/legis/legis_pck.htp_act_ text?idt=21846 (Last accessed 17 March 2016)

Massino, Jill. 2004. Anonimatul femeii in estetica Romaniei Ceausiste. [Women's Anonymity in Ceausescu's Romania's Aesthetics.] Bucharest: Bucharest University Press. http://ebooks.unibuc.ro/istorie/ciupala/ anonimatulfemeii.htm (Last accessed 12 January 2016)

Novak, Kathy. 2015. "Never Say No! South Korea's Pressure-cooker Work Culture.” CNN Regions +. http://edition.cnn.com/2015/07/23/asia/southkorea-work-culture/ (Last accessed 16 March 2016)

OECD. 2004. Women's Entrepreneurship: Issues and Policies. http://www.oecd. org/cfe/smes/31919215.pdf (Last accessed 12 March 2016)

OECD. 2013. Gender Wage Gap. http://www.oecd.org/gender/data/ genderwagegap.htm (Last accessed 15 January 2016)

OECD. 2014. Balancing Paid Work and Leisure. http://www.oecd.org/gender/ data/balancingpaidworkunpaidworkandleisure.htm. (Last accessed 18 February 2016)

OECD. 2015. Average Annual Hours Actually Worked per Worker. https://stats. oecd.org/Index.aspx?DataSetCode=ANHRS (Last accessed 19 February 2016)

Ofiteru, Andreea and Raluca Ion. 2014. Mihaela Miroiu. http://www.gandul. info/interviurile-gandul/mihaela-miroiu-femeilor-din-romania-li-sedatoreaza-reasezarea-justitiei-crearea-sentimentului-ca-marile-furturi-se-maisi-platesc-13460561 (Last accessed 13 January 2016)

Pădurariu, Cezar. 2014. Statutul femeii in Romania Comunista. [Woman's Status During Communist Romania.] http://adevarul.ro/locale/iasi/statutemancipat-1_531b15fe0d133766a8b878a7/index.html (Last accessed 14 January 2016)

Piti, Marius. 2010. Antreprenor "made in Romania". ["Made in Romania" Entrepreneur.] Fundatia post-privatizare [Post-privatization Foundation]. http://www.postprivatizare.ro/romana/antreprenor-made-in-romania/ (Last accessed 14 January 2016)

Ryan, Kyla. 2014. "South Korea's Failure to Support Working Women.” The Diplomat. http://thediplomat.com/2014/08/south-koreas-failure-to-supportworking-women/ (Last accessed 12 February 2016) 
Scărlătescu, Mircea. 2013. Antreprenoriatul in Romania. [Entrepreneurship in Romania.] http://sisc.ro/antreprenoriatul-in-romania/ (Last accessed 12 January 2016)

Terjesen, Siri and Ainsley Lloyd. 2015. The 2015 Female Entrepreneurship Index. Global Entrepreneuship and Development Institute. https://www.uvu. edu/uwlp/docs/2015femaleentrepreneurshipindex1.pdf (Last accessed 13 February 2016)

United Nations. 1948. The Universal Declaration of Human Rights. http://www. un.org/en/universal-declaration-human-rights/ (Last accessed 13 February 2016)

World Bank Group. 2016a. Ease of Doing Business in Korea. http://www. doingbusiness.org/data/exploreeconomies/korea/\#starting-a-business (Last accessed 13 February 2016)

World Bank Group. 2016b. Ease of Doing Business in Romania. http://www. doingbusiness.org/data/exploreeconomies/romania/\#starting-a-business (Last accessed 13 February 2016) 